\title{
Article
}

\section{In Vitro Screening of a 1280 FDA-Approved Drugs Library against Multidrug-Resistant and Extensively Drug-Resistant Bacteria}

\author{
Lucie Peyclit ${ }^{1,2}$, Sophie Alexandra Baron ${ }^{1,2}$, Linda Hadjadj ${ }^{1,2}$ and Jean-Marc Rolain ${ }^{1,2, *}$ \\ 1 Aix Marseille University, IRD, APHM, MEPHI, 19-21 Boulevard Jean Moulin, CEDEX 05, \\ 13385 Marseille, France; peyclit.lu@gmail.com (L.P.); sophiebaron363@gmail.com (S.A.B.); \\ linda.hadjadj@univ-amu.fr (L.H.) \\ 2 IHU-Méditerranée Infection, 19-21 Boulevard Jean Moulin, CEDEX 05, 13385 Marseille, France \\ * Correspondence: jean-marc.rolain@univ-amu.fr; Tel.: +33-4-13-73-24-01
}

Citation: Peyclit, L.; Baron, S.A.; Hadjadj, L.; Rolain, J.-M. In Vitro Screening of a 1280 FDA-Approved Drugs Library against MultidrugResistant and Extensively DrugResistant Bacteria. Antibiotics 2022, 11, 291. https://doi.org/10.3390/ antibiotics11030291

Academic Editor: Younes Smani

Received: 14 December 2021

Accepted: 20 February 2022

Published: 22 February 2022

Publisher's Note: MDPI stays neutral with regard to jurisdictional claims in published maps and institutional affiliations.

Copyright: (c) 2022 by the authors. Licensee MDPI, Basel, Switzerland. This article is an open access article distributed under the terms and conditions of the Creative Commons Attribution (CC BY) license (https:/ / creativecommons.org/licenses/by/ $4.0 /)$.

\begin{abstract}
Alternative strategies against multidrug-resistant (MDR) bacterial infections are suggested to clinicians, such as drug repurposing, which uses rapidly available and marketed drugs. We gathered a collection of MDR bacteria from our hospital and performed a phenotypic high-throughput screening with a 1280 FDA-approved drug library. We used two Gram positive (Enterococcus faecium P5014 and Staphylococcus aureus P1943) and six Gram negative (Acinetobacter baumannii P1887, Klebsiella pneumoniae P9495, Pseudomonas aeruginosa P6540, Burkholderia multivorans P6539, Pandoraea nosoerga P8103, and Escherichia coli DSM105182 as the reference and control strain). The selected MDR strain panel carried resistance genes or displayed phenotypic resistance to last-line therapies such as carbapenems, vancomycin, or colistin. A total of 107 compounds from nine therapeutic classes inhibited $>90 \%$ of the growth of the selected Gram negative and Gram positive bacteria at a drug concentration set at $10 \mu \mathrm{mol} / \mathrm{L}$, and $7.5 \%$ were anticancer drugs. The common hit was the antiseptic chlorhexidine. The activity of niclosamide, carmofur, and auranofin was found against the selected methicillin-resistant $S$. aureus. Zidovudine was effective against colistin-resistant $E$. coli and carbapenem-resistant K. pneumoniae. Trifluridine, an antiviral, was effective against E. faecium. Deferoxamine mesylate inhibited the growth of XDR P. nosoerga. Drug repurposing by an in vitro screening of a drug library is a promising approach to identify effective drugs for specific bacteria.
\end{abstract}

Keywords: multidrug-resistant bacteria; extensively-drug resistant bacteria; alternative strategy; drug repurposing; old drugs; antibiotic combination

\section{Introduction}

The emergence and spread of multidrug-resistant (MDR) pathogens represent a global healthcare question nowadays. Treating infections caused by MDR bacteria can be challenging for clinicians [1,2].

Multi-drug resistance is conventionally defined as resistance to one or more than one agents of three or more antibiotic classes [3]. Pathogens can also be qualified as extensively drug-resistant (XDR) if they remain susceptible to only one or two antimicrobial categories, or pandrug-resistant (PDR) if they are resistant to all of antimicrobial categories routinely tested in the laboratory [3]. The definition of "difficult-to-treat" resistant (DTR) bacteria seems to be more suitable for clinical practice, qualifying Gram negative bacteria when they are resistant to all first-line antibiotics, such as $\beta$-lactams or fluoroquinolones [4]. In any case, treatment of MDR bacterial infections can be limited due to resistance to first-line antibiotics and, now, to last-line therapies [5]. Resistant Gram positive cocci has shown resistance to glycopeptides [6]. Carbapenems or polymyxins may become ineffective against Gram negative strains due to the emergence of carbapenemase enzymes or structural changes [6]. Therapeutic impasses due to resistant bacteria are still rare, for 
now, but in some situations, clinicians must now tackle resistance to treat fragile patients [5]. Strategies to prevent therapeutic impasses are essential, especially for non-fermenting Gram negative bacteria. Indeed, they display a broad intrinsic resistance and are often infectious agents in immunocompromised patients [7]. As a result, many alternative strategies are now considered to optimize the treatment of infectious diseases by MDR bacteria, such as phage therapy, antibodies, probiotics, antivirulence factors, and drug repurposing [8,9].

The objective of drug repurposing is to identify a novel clinical use for an existing drugs approved in clinical medicine for a different indication. This method should be considered for treating new pathogens or agents for which no effective treatment is available [10]. Indeed, current pharmaceutical companies have no economic interest in developing new molecules to treat MDR bacteria that remain isolated cases [10]. As the situation is a public health issue [11], finding effective drugs already in our armamentarium can be an excellent alternative. Moreover, this offers advantages in terms of economic drug development or as an accelerator of the process by skipping preclinical trials [12]. To treat MDR infections, repurposing a drug seems to be an easy and rapid strategy. One of the methods to do this is a phenotypic-based assay, which consists of testing the efficacy of a large panel of drugs on the survival of a bacterium in vitro, as a high-throughput screening [10]. Using this strategy, some efficient drugs have been found so far, such as ribavirin against Candida strains [13], the antiretroviral zidovudine against Enterobacteriaceae [14] and the antihelminthic niclosamide against Staphylococcus aureus [15]. This strategy allows us to test a drug library at a single concentration that is sometimes higher than the concentration tested in routine testing [16].

Currently, scientific research is mainly directed towards finding new drugs against bacteria that belong to the ESKAPE group (including Enterococcus faecium, S. aureus, Klebsiella pneumoniae, Acinetobacter baumannii, Pseudomonas aeruginosa, and Enterobacter spp.). However, some "intrinsically" multi-drug resistant bacteria remain major challenges to be treated successfully. This is especially the case in cystic fibrosis (CF) patients, particularly after pulmonary transplant when post-transplantation immunosuppressive therapy increases the risk for opportunistic infections [17]. The impact of PDR bacterial pathogens contributes to greater mortality in the immunocompromised CF population because of treatment difficulties $[18,19]$.

The objective of our study was to decipher which drugs are still effective against bacteria that have a high level of drug resistance and pose potential treatment problems. We focused on various MDR or XDR bacteria, especially those found in CF patients. We investigated the action on the bacterial growth of drugs with an untested antimicrobial potential in vitro, which could be a first step towards a new drug repurposing strategy. We gathered a collection of various drug-resistant bacteria from our hospital and performed a phenotypic high-throughput screening with a 1280 FDA-approved drug library.

\section{Results}

\subsection{Antibiotic Resistance Profile and Genomic Support of Selected Strains Panel}

The two MDR Gram positive strains were a clinical strain of methicillin- and glycopeptidesresistant S. aureus P1943 carrying the mecA gene [20], and a clinical strain of vancomycinresistance E. faecium P5015 carrying a vanA gene (Table 1). Among the six Gram negative bacteria tested, three isolates (the Escherichia coli DSM 105182 strain [21], K. pneumoniae P9495, and A. baumannii P1887 [22]) were classified as MDR and three isolates were classified as XDR (P. aeruginosa P6540, Burkholderia multivorans P6539, and Pandoraea nosoerga P8103), as shown in Table 1. Four isolates were carbapenem-resistant (P9495, P1887, P6539, and P8103), including three producing NDM-1 for A. baumannii, OXA-48 for K. pneumoniae, and OXA-158 for P. nosoerga. Five of them were resistant to colistin, a last-line therapeutic drug (all except A. baumannii). The E. coli DSM 105182 strain carried a plasmid-mediated colistin resistance gene, $m c r-1$ (Table 1 ). 
Table 1. Antimicrobial susceptibility profiles and characterization from the selected panel according to the study of Magiorakos et al. [3]. MDR: multidrug-resistant; XDR: extensively drug-resistant.

\begin{tabular}{|c|c|c|c|}
\hline Strain and No. & Characterization [3] & $\begin{array}{l}\text { Non-Susceptibility to at Least One Agent } \\
\text { in All Those Classes }\end{array}$ & $\begin{array}{l}\text { Known Resistance } \\
\text { Genes }\end{array}$ \\
\hline S. aureus P1943 [20] & MDR & $\begin{array}{l}\text { Fluoroquinolones, anti-staphylococcal } \\
\beta \text {-lactams, glycopeptides, and macrolides }\end{array}$ & $\begin{array}{l}m e c A, \text { gyr } A, a a D, b l e O, \\
\text { and } e r m C\end{array}$ \\
\hline E. faecium P5015 & MDR & $\begin{array}{l}\text { Aminoglycosides, glycopeptides, and } \\
\text { tetracyclines }\end{array}$ & $\operatorname{van} A$ \\
\hline E. coli DSM 105182 [21] & MDR & $\begin{array}{c}\text { Polymyxins, tetracyclins, and } \\
\text { fluoroquinolones }\end{array}$ & $m c r-1$ \\
\hline K. pneumoniae P9495 & MDR & $\begin{array}{l}\text { Aminoglycosides, penicillins }+\beta \text {-lactamase } \\
\text { inhibitors, carbapenems, extended-spectrum } \\
\text { cephalosporins, fluoroquinolones, folate } \\
\text { pathway inhibitors, monobactacms, and } \\
\text { polymyxins }\end{array}$ & $b l a_{\mathrm{OXA}-48}$ \\
\hline A. baumannii P1887 [22] & MDR & $\begin{array}{c}\text { Aminoglycosides, carbapenems, } \\
\text { fluoroquinolones, penicillins + } \beta \text {-lactamase } \\
\text { inhibitors, extended-spectrum } \\
\text { cephalosporins, and folate pathway } \\
\text { inhibitors }\end{array}$ & $\begin{array}{l}\text { bla } a_{\mathrm{OXA}-51}, b l a_{\mathrm{OXA}-23} \\
\text { and } b l a_{\mathrm{NDM}-1}\end{array}$ \\
\hline P. aeruginosa P6540 & XDR & $\begin{array}{l}\text { Aminoglycosides, antipseudomonal } \\
\text { cephalosporins, antipseudomonal } \\
\text { fluoroquinolones, penicillins }+\beta \text {-lactamase } \\
\text { inhibitors, monobactacms, and polymyxins }\end{array}$ & \\
\hline B. multivorans P6539 & XDR & $\begin{array}{l}\text { Aminoglycosides, carbapenems, } \\
\text { cephalosporins, fluoroquinolones, } \\
\text { penicillins }+\beta \text {-lactamase inhibitors, } \\
\text { monobactacms, folate pathways inhibitors, } \\
\text { glycylcyclines, and polymyxins }\end{array}$ & \\
\hline P. nosoerga P8103 & XDR & $\begin{array}{c}\text { Aminoglycosides, carbapenems, } \\
\text { cephalosporins, fluoroquinolones, } \\
\text { penicillins + } \beta \text {-lactamase inhibitors, } \\
\text { rifamycins, folate pathways inhibitors, } \\
\text { tetracyclins, phosphonic acids, and } \\
\text { polymyxins }\end{array}$ & $b l a_{\mathrm{OXA}-158}$ \\
\hline
\end{tabular}

\subsection{General High-Throughput Screening Results}

Various hits with a growth inhibition rate of $90 \%$ or more were found, as shown in Figure 1, and the non-anti-infective compounds are listed for each bacterium in Table 2.

Table 2. Hits that are not in the "infectiology" therapeutic class but in all other classes.

\begin{tabular}{cc}
\hline Name of Strain & Hits Except “Infectiology" Class \\
\hline $\begin{array}{c}\text { S. aureus } \\
\text { P1943 }\end{array}$ & $\begin{array}{r}\text { Dronedarone hydrochloride (cardiovascular); thonzonium bromide (dermatology); auranofin } \\
\text { (metabolism); pinaverium bromide (neuromuscular); and } \\
\text { 5-fluorouracil, carmofur, and gemcitabine (oncology) }\end{array}$ \\
$\begin{array}{c}\text { E. faecium } \\
\text { P5015 }\end{array}$ & $\begin{array}{c}\text { Amiodarone and dronedarone hydrochloride (cardiovascular); clomiphene citrate (Z and E) } \\
\text { (endocrinology); auranofin (metabolism); tamoxifen citrate, gemcitabine, carmofur, floxuridine, } \\
\text { pemetrexed disodium, raltitrexed, 5-fluorouracil, and methotrexate (oncology) }\end{array}$ \\
\hline $\begin{array}{c}\text { E. coli } \\
\text { DSM } 105182\end{array}$ & Azaperone and lomerizine hydrochloride (central nervous system) \\
\hline $\begin{array}{c}\text { P. nosoerga } \\
\text { P8103 }\end{array}$ & Deferoxamine mesylate (hematology) \\
\hline
\end{tabular}




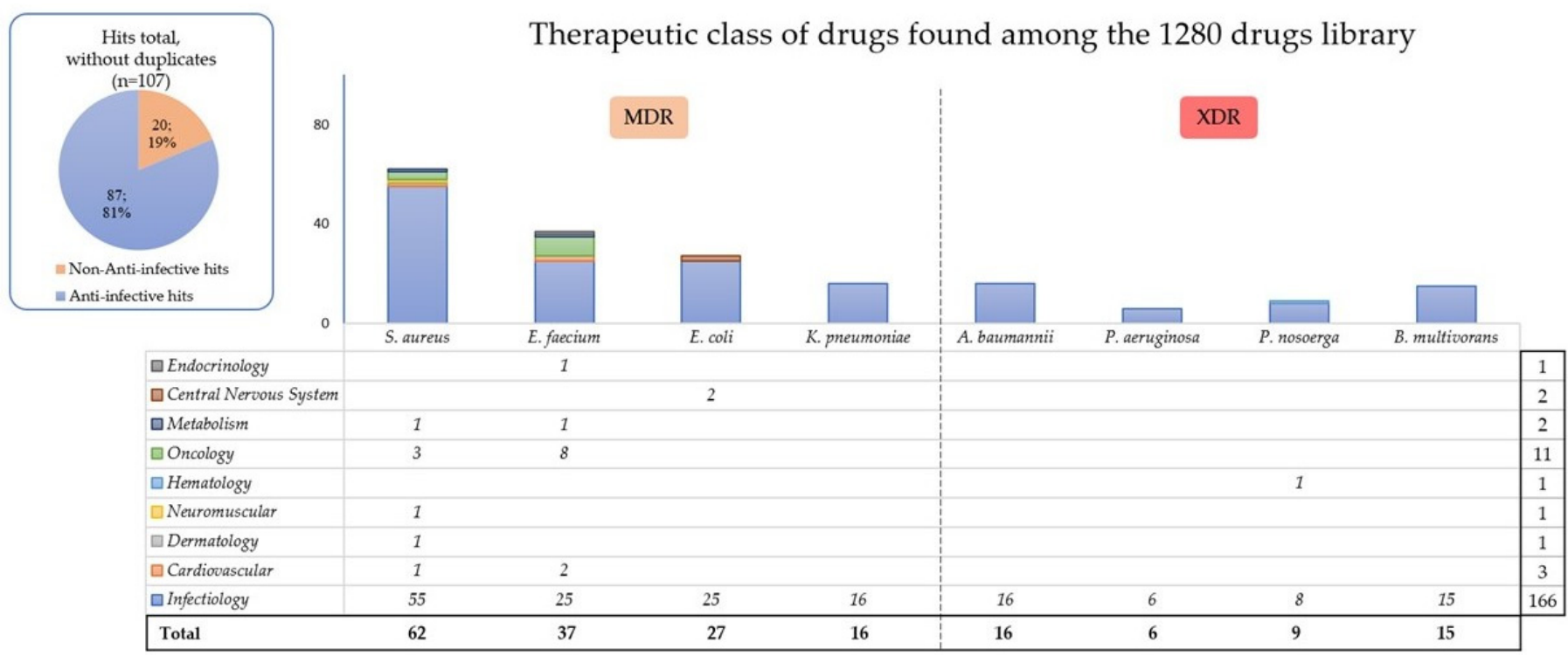

Figure 1. Hits found after an in vitro screening of the 1280 drugs library for each bacterium according to their therapeutic class. On the left, we discarded the duplicates and found 107 hits for all the Gram positive and negative bacteria. Some drugs are classified in various therapeutic classes and can be either antibacterial, antifungal, or antiviral, so we first considered the antibacterial effect in our counting or the major known effect. This chart highlights that most molecules that are active in vitro against bacterial growth are anti-infectives. Only a few options among the 1280 molecules tested can inhibit the bacterial growth of $P$. nosoerga or P. aeruginosa. All the compounds per bacterium are detailed in Supplementary Table S1. MDR: multidrug-resistant; XDR: extensively drug-resistant.

Overall, 62 drugs inhibited at least $90 \%$ of the S. aureus growth, 37 for E. faecium, 27 for E. coli, 16 for K. pneumoniae, and 16 for A. baumannii (Figure 1). Among the XDR bacteria, 6 hits were found for P. aeruginosa, 9 for P. nosoerga, and 15 for B. multivorans.

Overall, among these nine therapeutic classes involved, we found 107 different hits for all the selected Gram positive and Gram negative pathogens in total, including $20(19 \%)$ beyond antimicrobial agents (Figure 1). Among them, eight (7.5\%) oncology drugs were found active on Gram positive bacteria, namely: tamoxifen citrate, gemcitabine, carmofur, floxuridine, pemetrexed disodium, raltitrexed, 5-fluorouracil, and methotrexate (Table 2). For the two MDR Gram positive bacteria tested, 23 common hits were found, including an antiarrhythmic (dronedarone hydrochloride), two antiseptics (chlorhexidine and hexachlorophene), twelve antibacterials, an antiprotozoal (monensin sodium salt), an antihelminthic (closantel), an antirheumatic (auranofin), two antifungals (oxiconazole and sulconazole nitrate), and three antineoplastics (5-fluorouracil, carmofur, and gemcitabine; Figure 2). Gram negative bacterial hits all belonged to antimicrobial agents, except two (azaperone and lomerizine hydrochloride) for E. coli and deferoxamine mesylate for $P$. nosoerga (Figure 1 and Table 2). Between Gram negative and Gram positive bacteria, the antiseptic chlorhexidine was the only common compound among all of the therapeutic class (Figure 2).

\subsection{Main Hits by Species}

All hits are reported in Figure 2, but we mentioned below those that required our attention for each species.

Various antibiotics (furazolidone and monensin) and antiseptics were effective, but alsoantihelminthics, such as closantel, niclosamide, or pyrvinium pamoate, or antifungals, such as sulconazole, inhibited this $S$. aureus. In addition, the antiarrhythmic dronedarone was also effective against this strain (Table 2). Among the compounds, we noticed that antifungal azoles were effective against $E$. faecium (butoconazole, econazole, oxiconazole, tioconazole, and sulconazole). All these drugs are intended for topical use. Amiodarone, 
methotrexate, and an antiviral drug, trifluridine, were also found to be effective (Table 2). The same clomiphene citrate and tamoxifen, selective oestrogen receptor modulators, inhibited the growth of the resistant E. faecium. E. coli bacterial growth was inhibited by anti-infective drugs such as known antibiotics or antiseptics, but also by an antiviral, zidovudine. The veterinary neuroleptic azaperone and the migraine treatement lomerizine hydrochloride (central nervous system (CNS)) were two non-anti-infective drugs effective against E. coli (Table 2).

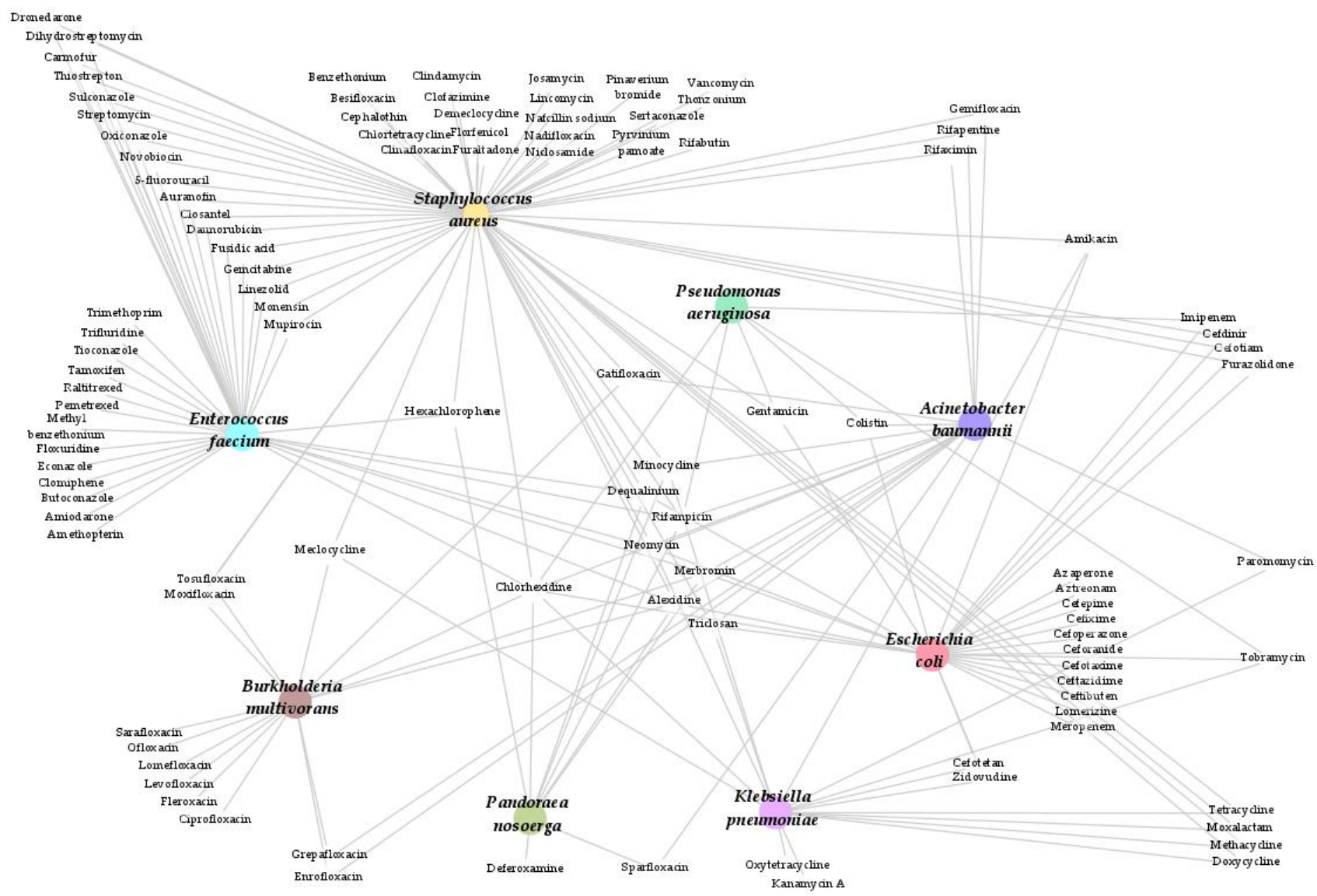

Figure 2. Compounds with a common efficacy on the growth of Gram positive or Gram negative bacteria in this 1280 drugs screening at $10 \mu \mathrm{mol} / \mathrm{L}$. These molecules must be further tested more carefully, particularly regarding CMI assays, pharmacokinetics and pharmacodynamics, and administration modes in relation to the type of infection, etc.

Antibiotics such as tetracyclines or aminoglycosides and the antiviral zidovudine inhibited the growth of K. pneumoniae.

Drugs not belonging to the anti-infectious class showed very limited efficacy in inhibiting the growth of A. baumannii. As anti-infectious drugs, fluroquinolones, rifamycin, and antiseptics (merbromin, triclosan, and chlorhexidine) were found to be the most effective against the selected carbapenem-resistant $A$. baummanii. Colistin was also effective at $11.5 \mathrm{mg} / \mathrm{L}(10 \mu \mathrm{mol} / \mathrm{L})$.

Against these XDR non-fermenting Gram negative bacteria (P. aeruginosa, B. multivorans, and P. nosoerga), fewer drugs showed action on their growth, and they were mostly antiseptics or antibiotics. However, this screening may point to potential combination or higher dosage regimens on drugs that are still effective against XDR strains (Table 3). For instance, higher concentrations of colistin were effective against $P$. aeruginosa when it was initially resistant in our routine tests (Table 2). In terms of drug repurposing, by reducing the detection limit to $55 \%$, we were able to find that an anti-rheumatic agent, auranofin, 
was effective against $P$. aeruginosa. Deferoxamine mesylate was the only non-anti-infective hit against $P$. nosoerga (Table 2 ).

Table 3. Possible alternative solutions for the selected XDR strains with in vitro activity. If the doses of these antibiotics are increased, it is to consider improved efficacy. However, this must be monitored if the dosages would be beyond the recommendations (for renal function, serum concentrations, etc.) and these molecules are not recommended for use as monotherapy.

\begin{tabular}{cccc}
\hline & Combination Therapy & Drug Repurposing & Increased Dosages \\
\hline P. aeruginosa & $\begin{array}{c}\text { Rifampicin + imipenem } \\
\text { Colistin + imipenem }\end{array}$ & $\begin{array}{c}\text { Auranofin } \\
(+ \text { colistin } \pm \text { ceftazidime })\end{array}$ & Colistin \\
\hline P. nosoerga & Rifampicin + minocyclin & $\begin{array}{c}\text { Deferoxamine + ascorbic acid } \\
(+ \text { gentamicin })\end{array}$ & Rifampicin \\
\hline B. multivorans & $\begin{array}{c}\text { Fluoroquinolones } \\
+\beta \text {-lactams }\end{array}$ & - & Fluoroquinolones \\
\hline
\end{tabular}

\subsection{Comparison with Data from the Literature}

We compared our results with pharmacokinetic data from literature studies for each bacterium in order to repurpose our hits (Supplementary Table S2).

The concentration tested for the antiarrhythmic dronedarone in the screening was effective against $S$. aureus, but was much higher than the plasma concentrations found in humans (tested at $5.9 \mathrm{mg} / \mathrm{L}$ and found from 0.084 to $0.167 \mathrm{mg} / \mathrm{L}$ in human plasma) [23]. However, amiodarone was active as an achievable concentration on E. faecium (tested at $6.5 \mathrm{mg} / \mathrm{L}$ and found at $1170 \mathrm{mg} / \mathrm{L}$ in human plasma). This antibacterial effect on Gram positive bacteria has not been previously demonstrated to the best of our knowledge. The narrow therapeutic window of antiarrhythmics and their side-effects leads to a challenging clinical use and can thus be controversial [24].

Anticancer drugs have also shown some effectiveness against Gram positive bacteria. In this screening, gemcitabine was effective at $2.6 \mathrm{mg} / \mathrm{L}$ for S. aureus and E. faecium. In the literature, the maximum serum concentration (Cmax) could be $2 \mathrm{mg} / \mathrm{L}$ with infusion at $600 \mathrm{mg} / \mathrm{m}^{2}$ [25] or $40.9 \mathrm{mg} / \mathrm{L}$ with an administration of $2000 \mathrm{mg} / \mathrm{m}^{2}$ [26].

Previous pharmacokinetics data on deferoxamine mesylate revealed a steady-state concentration of $3.9 \mathrm{mg} / \mathrm{L}$ using continuous intravenous deferoxamine infusion at $50 \mathrm{mg} / \mathrm{kg} / \mathrm{d}$ [27], which is in the same range as our screening concentration $(5.6 \mathrm{mg} / \mathrm{L}-10 \mu \mathrm{mol} / \mathrm{L})$.

\section{Discussion}

\subsection{What Are the Potential Therapeutic Options for Treating These MDR Bacteria?}

After analyzing the results of this screening of 1280 molecules on a panel of XDR or MDR strains, we found several possible options that could help to fight these bacteria after assessing their effective antibacterial potential and performing additional assays.

\subsection{To Find a Common Hit}

The only common hit we found among 1280 drugs for this panel was chlorhexidine. By disrupting the cell membrane and interfering with osmosis [28] (Figure 3), this widely antiseptic and disinfectant is used, for instance, as a topical agent for skin decolonization or to sterilize surgical tools [29]. After all, this common result is in favor of the chlorhexidine bathing recommended before performing a transplant to limit Gram negative bacterial infections [30,31]. Its efficacy among MDR and XDR bacteria is also supported by previous studies on VRE [32], MRSA [33], carbapenemase-producing K. pneumoniae [34], or MDR Gram negative [35]. Despite its wide use in prevention, its effectiveness must be monitored for the development of resistance or adverse effects [36]. Furthermore, not finding a common hit for these bacteria for systemic use is not worrisome, as this would also affect the vital microbiota. 


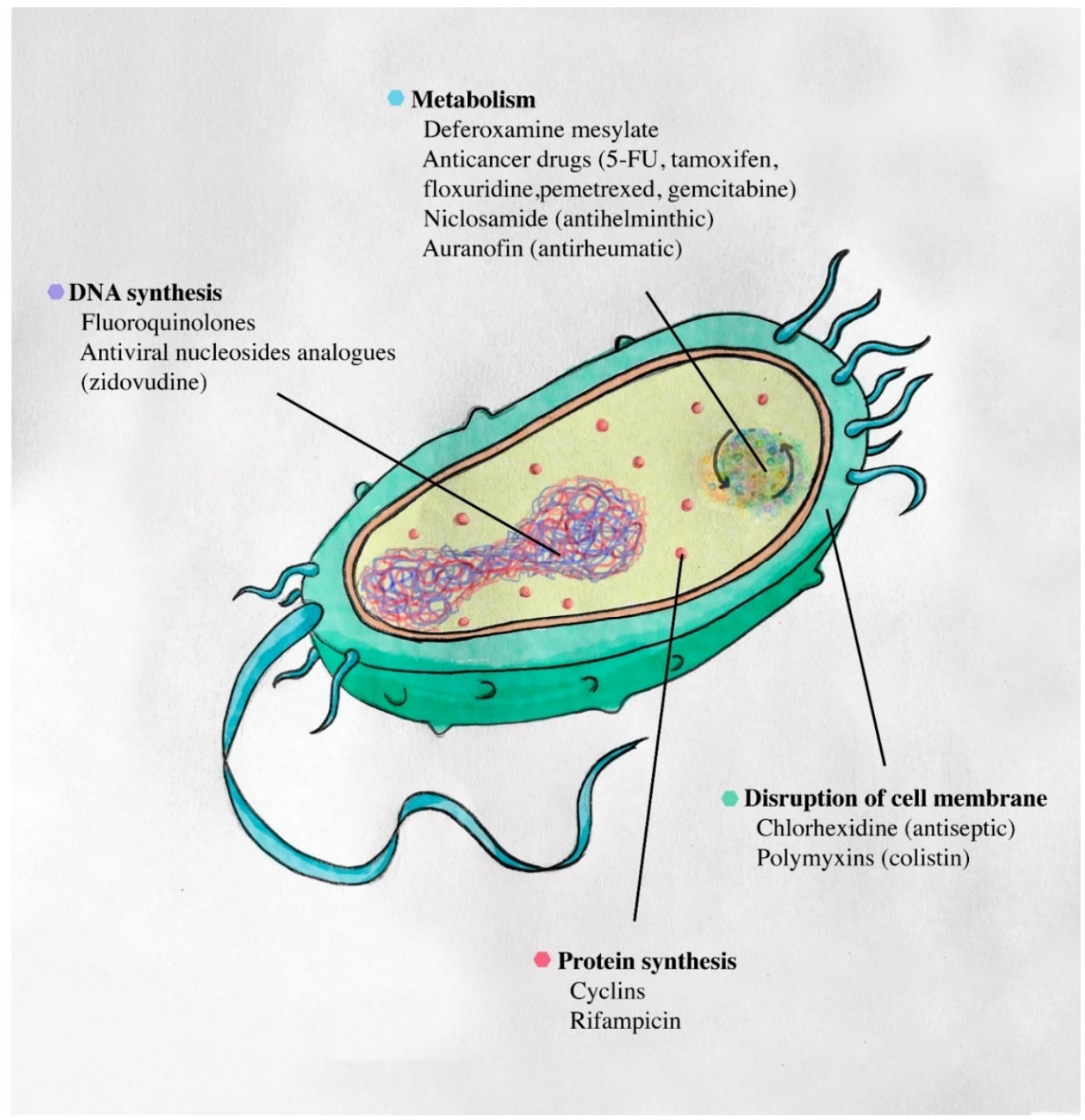

Figure 3. Mechanisms of action of in vitro effective drugs on Gram negative bacteria tested at $10 \mu \mathrm{M}$.

\subsection{To Repurpose a Molecule}

In this study, some hits were specifically efficient against bacteria and were not initially marketed for that use: they could be tied to drug repurposing [10]. In this way, the antihelminthic niclosamide, with more than $90 \%$ inhibition of S. aureus, has already been widely proposed to treat drug-resistant bacteria [15,37-39] (Figure 3). Its antibacterial potential has been described for hospital acquired infections as MRSA [15] or intestinal decolonization of VRE [39], but also in combination with colistin to treat colistin-resistant Gram negative bacilli infections $[37,38]$. As carmofur and auranofin are also effective against MRSA, they have been further investigated for their anti-biofilm activity [40]. The efficacy of clomiphene on E. faecium confirmed the idea of repurposing some oestrogen receptor antagonists to treat infectious diseases [41]. In addition, the antimetabolite methotrexate was effective against the growth of E. faecium and could act by inhibiting dihydrofolate reductase, such as trimethoprim, which was also effective. An old study conducted in 1974 reported methotrexate activity with a MIC of $0.15 \mu \mathrm{g} / \mathrm{L}$ against Streptococcus faecium [42], formerly named E. faecium, confirmed on $S$. faecalis ten years after [43]. The antibacterial effect of zidovudine on E. coli and K. pneumoniae, previously shown in 1987 [44], confirmed our report about its potential use to treat infections on colistin-resistant Gram negative bacteria [14]. 
However, drug repurposing is not feasible for all cases. Concerning E. coli, the veterinary use of azaperone [45] and the low serum concentration for lomerizine in humans [46] do not allow these CNS drugs for immediate clinical use, but require further investigations (Supplementary Table S2). Paromomycin, an aminoglycoside effective against K. pneumoniae, is usually used to treat parasite infections such as amebiasis. Nevertheless, like neomycin, these aminoglycosides display a poor intestinal absorption, which is not suitable for systemic infections. Paromomycin can still be used for the intestinal decolonisation of resistant Enterobacteriaceae [47]. Furthermore, colistin and methotrexate are compounds with known and feared adverse effects in clinical practice.

\subsection{Using Drug Associations}

A combination of drugs consisting of old drugs, broad spectrum antibiotics, and nonanti-infective compounds, may provide killing effects [48]. Rifampicin and minocycline, effective on $P$. nosoerga, should be verify the effectiveness of the combination with a checkerboard assay, as it already showed goods results [49]. Fluoroquinolones in combination with $\beta$-lactams are also promising, as shown by in vitro testing against Burkholderia cepacian [50] or evaluation in a large cohort study against Gram negative bacilli bacteraemia [51].

Combination therapy is recommended for MDR bacteria treatment [10]. It allows clinicians to use drugs at lower concentrations than in monotherapy through a synergistic effect, as shown by Lee J. H. et al. with rifampicin and colistin against MDR A. baumannii [52]. In vitro studies reported a good efficiency of imipenem in combination with rifampicin or colistin against MDR clinical isolates of P. aeruginosa [53,54]. Furthermore, auranofin, which was effective against the selected XDR P. aeruginosa, has been studied in combination with polymyxins on Gram negative species that permeabilize the outer membrane of Gram negative and help auranofin enter the bacteria cell (Figure 3). The combination with colistin on P. aeruginosa showed a synergistic effect [55] and the addition of ceftazidime inhibited $>80 \%$ growth of 10 MDR pathogens, including P. aeruginosa [56].

Trifluridine, an antiviral molecule, is used in monotherapy as anti-herpesvirus eye drops. It has a low bioavailability after clinical administration as it is rapidly degraded via thymidine phosphorylase. Therefore, in combination with a potent thymidine phosphorylase inhibitor, tipiracil has been studied for antineoplastic use [57]. This combination could be tested on resistant Enterococcus sp. against systemic infections.

Deferoxamine mesylate is used to treat iron overdose as hemochromatosis because it binds iron and aluminium. This drug is effective against $P$. nosoerga and is not known to date as being used for antibacterial monotherapy. By complexing with aluminum or gallium, deferoxamine has a Trojan horse effect, carrying these toxic metal ions into the bacterial metabolism [58] (Figure 3). Moreover, when used with ascorbic acid, deferoxamine showed a bacterial growth inhibiting effect [59], and added to gentamicin, this triple combination displayed a synergistic effect against some E. coli strains [60]. As it is easy to apply, this association should be assessed by performing MIC assays on these strains.

\subsection{Damaging Basic Mechanisms of Bacteria}

Although using old drugs or combinations of drugs can be successful, drugs acting on essential mechanisms such as DNA or the protein cycle of all bacteria are frequently represented (Figure 3).

In addition, our screening concentration was of four oncology molecules in the human concentration range (Supplementary Table S2). Some activities have been already reported, like 5-fluorouracil, tamoxifen, floxuridine, pemetrexed disodium, and gemcitabine in Gram positive or in resistant Gram negative strains [10,61,62]. A study testing tamoxifen in combination with polymyxins against XDR Gram negative pathogens used an achievable concentration for oral administration [62]. However, we are aware that anti-cancer drugs would not only target bacteria, but would also regulate immunity and host response [63]. As these drugs can disrupt the immune response, it is doubtful whether their use to fight infectious diseases would be beneficial. In a review by Soo V. et al., similarities between 
cancer cells and bacterial infections encouraged the use of agents with a broad activity, which act on the cell cycle [64] (Figure 3). Society might be frightened to try such therapies due to the many side effects of treating infectious diseases. However, given our results, using anticancer drugs might be the only solution to treat patients infected with a XDR bacterium for which no treatment is available, despite their toxicity [16].

On the other hand, fluoroquinolones and tetracyclines were effective in most of our panel. These antibiotics have a broad spectrum, with activity on Gram positive and Gram negative bacteria. Cyclins inhibit protein synthesis and fluoroquinolones prevent DNA replication and transcription - these mechanisms are essential for bacteria to live and are therefore highly conserved in all species (Figure 3). However, bacteria can adapt quickly to these antibiotics, developing several resistance mechanisms, leading to cross-resistance and increasing MIC [65]. The selected B. multivorans was previously ciprofloxacin-resistant with disk diffusion, but became susceptible in the screening test, where the concentration tested was $3.31 \mathrm{mg} / \mathrm{L}(10 \mu \mathrm{mol} / \mathrm{L})$. This difference was due to the concentration used in the screening method being higher than the usual dose used in sensitivity testing and medical practice. Using a higher concentration of ciprofloxacin or other fluoroquinolones could treat B. multivorans infection (Table 3). This is in accordance with previous successful studies with an increase of dosage regiments against PDR bacteria [66]. After assessment of the risks and benefits of the treatment, this could lead to a better clinical response and circumvent resistance [16].

Finally, few other anti-infective agents were effective pointing essential mechanisms. Antiviral nucleosides analogues like trifluridine (E. faecium) or zidovudine (against Enterobacteriaceae [14]) targeted the inhibition of DNA synthesis, which could explain their effect on bacterial inhibition growth (Figure 3). In addition to having some synergy with antibiotics, nucleoside analogues should be considered as new weapons against bacterial infection, as suggested by A. E. J. Yssel et al. [61,67].

\subsection{Personalizing the Treatment in a Compassionnal Approach}

Access to a rapid screening method for many commercially available molecules is a method that can help clinicians propose a therapeutic option to patients when faced with a therapeutic impasse. This method, which should be limited to the most severe cases, allows for the identification of molecules of interest, for which the MIC must be checked to assess whether it is achievable in vivo. Similarly, the in vivo efficacy of the identified molecules will depend on the data in the literature. For instance, this could be a solution for opportunistic bacteria that have many resistance determinants such as Burkholderiales [68]. The clinical impact of this screening can be significant, as these molecules have already been approved and marketed and they can be quickly made available to clinicians. The risk-benefit of patients facing such infections must be assessed as a compassionnal treatment, as well as the management of certain adverse effects and the toxicity that can be controlled [16]. This strategy has been applied to the emergence of new pathogens for which no treatment is yet available because of the SARS-CoV-2 outbreak [69].

In this study, we investigate the in vitro efficacy of 1280 FDA-approved drugs among eight MDR and XDR clinical bacteria displaying various resistance phenotypes and resistance genes. We screened a library of 1280 drugs against a collection of bacteria. A total of 107 compounds from nine different therapeutic classes inhibited $>90 \%$ growth of the chosen Gram negative and Gram positive bacteria. In view of the hits found, we noticed that the difficulty in finding active compounds on Gram negative bacteria is greater than for Gram positive bacteria. This reflects our clinical practice issues with the MDR Gram negative bacteria, and especially the non-fermenting Gram negative.

Some of these results represent a first step towards the use of a drug repurposing strategy for the treatment of MDR bacterial infections. Nevertheless, these molecules must be further studied on a case-by-case basis to verify their antibacterial efficacy, understand their mechanisms of action, and confirm their suitability for a relevant administration. Assessing a potential antibacterial must use reference bacterial isolates for obtaining the 
MIC range, MIC50, and MIC90. This protocol is, after all, becoming established in our laboratory as clinical screening for special patients with XDR bacterial infection. Finally, it might be judicious to create a network of different fields of expertise to promote the investigation of these new options, so that each option can be explored in detail, with all the necessary analyses to achieve the final goal-finding new therapeutic solutions to deal with antibiotic resistance.

\section{Materials and Methods}

\subsection{Collection and Susceptibility of Bacterial Strains}

With the exception of the $m c r-1$ reference strain E. coli (DSM 105182), all strains (E. faecium P5014, S. aureus P1943, A. baumannii P1887, K. pneumoniae P9495, P. aeruginosa P6540, $B$. multivorans P6539, and P. nosoerga P8103) were collected for their antibiotic resistance profile from clinical samples. To determine antibiotic susceptibility, the standard disk diffusion method and breakpoint assessment were performed according to the European Committee of Antimicrobial Susceptibility Testing (EUCAST) recommendations. When breakpoints were not available in EUCAST, we used recommendations from the French Society of Microbiology (CA-SFM). We used the previously published definitions from the study of A. Magiorakos [3] to categorize the MDR (acquired non-susceptibility to at least one agent in three or more antimicrobial categories) and XDR (non-susceptibility to at least one agent in all but two or fewer antimicrobial categories) phenotypes.

\subsection{Preparation of Isolates}

The isolates were inoculated on a TSA medium (Trypticase soy agar, BioMérieux, Marcy-l'Étoile, France) at $37^{\circ} \mathrm{C}$ for $18-24 \mathrm{~h}$. The strains were suspended at $10^{8} \mathrm{CFU} / \mathrm{mL}$ in $0.9 \% \mathrm{NaCl}$ and diluted $1 / 100\left(10^{6} \mathrm{CFU} / \mathrm{mL}\right)$ in cation adjusted Mueller-Hinton broth media (CAMHB, Merck KGaA, Darmstadt, Germany).

\subsection{High-Throughput Screening Assay}

The screening test was performed on 96-well microplates with 1280 FDA-approved drugs from a chemical library (Prestwick-Chemical, Illkirch Graffenstaden, France), in which $16 \%$ of the drugs were initially used for the nervous system, $14 \%$ for the cardiovascular system, and $14 \%$ of the anti-infectives for systemic use. Regardless of the protocol, the final drug concentration in each well was always $10 \mu \mathrm{mol} / \mathrm{L}$. Dilution of the initial plates was performed to achieve a DMSO (dimethyl sulfoxide) concentration of less than $0.1 \%$ in all of the final plates (initial concentration of $10 \%$ ).

The plates were prepared in duplicates with $80 \mu \mathrm{L}$ of CAMHB, $10 \mu \mathrm{L}$ of drugs at $100 \mu \mathrm{mol} / \mathrm{L}$, and $10 \mu \mathrm{L}$ of each bacterium at $10^{6} \mathrm{CFU} / \mathrm{mL}$, and with negative and positive controls, incubated at $37^{\circ} \mathrm{C}$ for $18-24 \mathrm{~h}$ shaking at $300 \mathrm{rpm}$.

Bacterial growth was measured by spectrophotometry (Multiskan Spectrum, Thermo Fisher Scientific, Waltham, MA, USA). Then, the bacterial growth inhibition rate was calculated with the following equation as a function of absorbance $(A)$ in the wells:

$$
\text { Bacterial growth inhibition }(\%)=\left[1-\left(\frac{A_{\text {sample }}-A_{\text {negative control }}}{A_{\text {positive control }}-A_{\text {negative control }}}\right)\right] \times 100
$$

Hits were selected when the growth inhibition rate was greater than $90 \%$. 


\begin{abstract}
Supplementary Materials: The following supporting information can be downloaded at: https: / / www.mdpi.com/article/10.3390/antibiotics11030291/s1, Table S1: Molecules and their therapeutic class with a bacterial growth inhibition percentage higher than $90 \%$ for the bacteria tested, Table S2: Comparison of non-anti-infective hits with human PK data from literature. (References [70-78] are cited in the supplementary materials).
\end{abstract}

Author Contributions: L.P., S.A.B., L.H. and J.-M.R. designed the study, and drafted and revised the manuscript. L.P. performed microbiology analyses. All authors have read and agreed to the published version of the manuscript.

Funding: This work was supported by the French Government under the «Investissements d'avenir» (Investments for the Future) program managed by the Agence Nationale de la Recherche (ANR, fr: National Agency for Research), (reference: Méditerranée Infection 10-IAHU-03). This work was supported by Région Provence-Alpes-Côte d'Azur and European funding FEDER PRIMI.

Acknowledgments: We thank the designer Juan Manuel Osorio Rozo for Figure 3 (https: / /www. behance.net/juanmanuelosoriorozo, accessed on 18 May 2021).

Conflicts of Interest: The authors declare that they have no competing interest.

\title{
References
}

1. Bassetti, M.; Righi, E.; Carnelutti, A.; Graziano, E.; Russo, A. Multidrug-resistant Klebsiella pneumoniae: Challenges for treatment, prevention and infection control. Expert Rev. Anti. Infect. Ther. 2018, 16, 749-761. [CrossRef] [PubMed]

2. Musso, M.; Mosti, S.; Gualano, G.; Mencarini, P.; Urso, R.; Ghirga, P.; Rianda, A.; Del Nonno, F.; Goletti, D.; Palmieri, F. Hepatitis $\mathrm{C}$ virus infection: A challenge in the complex management of two cases of multidrug-resistant tuberculosis. BMC Infect. Dis. 2019, 19, 882. [CrossRef]

3. Magiorakos, A.P.; Srinivasan, A.; Carey, R.B.; Carmeli, Y.; Falagas, M.E.; Giske, C.G.; Harbarth, S.; Hindler, J.F.; Kahlmeter, G.; Olsson-Liljequist, B.; et al. Multidrug-resistant, extensively drug-resistant and pandrug-resistant bacteria: An international expert proposal for interim standard definitions for acquired resistance. Clin. Microbiol. Infect. 2012, 18, 268-281. [CrossRef]

4. Kadri, S.S.; Adjemian, J.; Lai, Y.L.; Spaulding, A.B.; Ricotta, E.; Prevots, D.R.; Palmore, T.N.; Rhee, C.; Klompas, M.; Dekker, J.P.; et al. Difficult-to-Treat Resistance in Gram-negative Bacteremia at 173 US Hospitals: Retrospective Cohort Analysis of Prevalence, Predictors, and Outcome of Resistance to All First-line Agents. Clin. Infect. Dis. 2018, 67, 1803-1814. [CrossRef] [PubMed]

5. Sherry, N.; Howden, B. Emerging Gram negative resistance to last-line antimicrobial agents fosfomycin, colistin and ceftazidimeavibactam-epidemiology, laboratory detection and treatment implications. Expert Rev. Anti-Infect. Ther. 2018, 16, 289-306. [CrossRef]

6. Sirijan, S.; Nitaya, I. Mechanisms of Antimicrobial Resistance in ESKAPE Pathogens. BioMed Res. Int. 2016, $2016,2475067$. [CrossRef]

7. El Chakhtoura, N.G.; Saade, E.; Iovleva, A.; Yasmin, M.; Wilson, B.; Perez, F.; Bonomo, R.A. Therapies for multidrug resistant and extensively drug-resistant non-fermenting Gram-negative bacteria causing nosocomial infections: A perilous journey toward 'molecularly targeted' therapy. Expert Rev. Anti. Infect. Ther. 2018, 16, 89-110. [CrossRef] [PubMed]

8. Koulenti, D.; Song, A.; Ellingboe, A.; Abdul-Aziz, M.H.; Harris, P.; Gavey, E.; Lipman, J. Infections by multidrug-resistant Gram-negative Bacteria: What's new in our arsenal and what's in the pipeline? Int. J. Antimicrob. Agents 2019, 53, 211-224. [CrossRef] [PubMed]

9. Aslam, B.; Wang, W.; Arshad, M.I.; Khurshid, M.; Muzammil, S.; Rasool, M.H.; Nisar, M.A.; Alvi, R.F.; Aslam, M.A.; Qamar, M.U.; et al. Antibiotic resistance: A rundown of a global crisis. Infect. Drug Resist. 2018, 11, 1645-1658. [CrossRef]

10. Peyclit, L.; Baron, S.A.; Rolain, J.-M. Drug repurposing to fight colistin and carbapenem-resistant bacteria. Front. Cell. Infect. Microbiol. 2019, 9, 193. [CrossRef]

11. OMS (Organisation Mondiale de la Santé) Résistance Aux Antibiotiques. Available online: http://www.who.int/mediacentre/ factsheets/antibiotic-resistance/fr/ (accessed on 9 February 2018).

12. Law, G.L.; Tisoncik-Go, J.; Korth, M.J.; Katze, M.G. Drug repurposing: A better approach for infectious disease drug discovery? Curr. Opin. Immunol. 2013, 25, 588-592. [CrossRef] [PubMed]

13. Yousfi, H.; Cassagne, C.; Ranque, S.; Rolain, J.M.; Bittar, F. Repurposing of ribavirin as an adjunct therapy against invasive Candida strains in an in vitro study. Antimicrob. Agents Chemother. 2019, 63, e00263-19. [CrossRef]

14. Peyclit, L.; Baron, S.A.; Yousfi, H.; Rolain, J.M. Zidovudine: A salvage therapy for $m c r-1$ plasmid-mediated colistin-resistant bacterial infections? Int. J. Antimicrob. Agents 2018, 52, 11-13. [CrossRef] [PubMed]

15. Rajamuthiah, R.; Fuchs, B.B.; Conery, A.L.; Kim, W.; Jayamani, E.; Kwon, B.; Ausubel, F.M.; Mylonakis, E. Repurposing salicylanilide anthelmintic drugs to combat drug resistant Staphylococcus aureus. PLoS ONE 2015, 10, e0124595. [CrossRef] [PubMed] 
16. Rolain, J.M.; Baquero, F. The refusal of the Society to accept antibiotic toxicity: Missing opportunities for therapy of severe infections. Clin. Microbiol. Infect. 2016, 22, 423-427. [CrossRef]

17. Huang, H.C.; Weigt, S.S.; Derhovanessian, A.; Palchevskiy, V.; Ardehali, A.; Saggar, R.; Saggar, R.; Kubak, B.; Gregson, A.; Ross, D.J.; et al. Non-tuberculous mycobacterium infection after lung transplantation is associated with increased mortality. J. Hear. Lung Transplant. 2011, 30, 790-798. [CrossRef] [PubMed]

18. Snell, G.; Reed, A.; Stern, M.; Hadjiliadis, D. The evolution of lung transplantation for cystic fibrosis: A 2017 update. J. Cyst. Fibros. 2017, 16, 553-564. [CrossRef]

19. Scoffone, V.C.; Chiarelli, L.R.; Trespidi, G.; Mentasti, M.; Riccardi, G.; Buroni, S. Burkholderia cenocepacia infections in cystic fibrosis patients: Drug resistance and therapeutic approaches. Front. Microbiol. 2017, 8, 1592. [CrossRef]

20. Rolain, J.-M.; Francois, P.; Hernandez, D.; Bittar, F.; Richet, H.; Fournous, G.; Mattenberger, Y.; Bosdure, E.; Stremler, N.; Dubus, J.-C.; et al. Genomic analysis of an emerging multiresistant Staphylococcus aureus strain rapidly spreading in cystic fibrosis patients revealed the presence of an antibiotic inducible bacteriophage. Biol. Direct 2009, 4, 1. [CrossRef]

21. Fonseca e Silva, D.; Silva-Dias, A.; Gomes, R.; Martins-Oliveira, I.; Ramos, M.H.; Rodrigues, A.G.; Cantón, R.; Pina-Vaz, C. Evaluation of rapid colistin susceptibility directly from positive blood cultures using a flow cytometry assay. Int. J. Antimicrob. Agents 2019, 54, 820-823. [CrossRef]

22. Bakour, S.; Touati, A.; Bachiri, T.; Sahli, F.; Tiouit, D.; Naim, M.; Azouaou, M.; Rolain, J.M. First report of 16S rRNA methylase ArmA-producing Acinetobacter baumannii and rapid spread of metallo- $\beta$-lactamase NDM-1 in Algerian hospitals. J. Infect. Chemother. 2014, 20, 696-701. [CrossRef] [PubMed]

23. Maria, T.; Ioannis, B. Dronedarone pharmacokinetics. Front. Pharmacol. 2010, 1. [CrossRef]

24. Mankad, P.; Kalahasty, G. Antiarrhythmic Drugs: Risks and Benefits. Med. Clin. N. Am. 2019, 103, 821-834. [CrossRef] [PubMed]

25. Alharbi, A.F.; Kratzke, R.A.; D'Cunha, J.; Maddaus, M.A.; Sanghavi, K.; Kirstein, M.N. Gemcitabine and metabolite pharmacokinetics in advanced NSCLC patients after bronchial artery infusion and intravenous infusion. Cancer Chemother. Pharmacol. 2019, 83, 387-391. [CrossRef] [PubMed]

26. Fogli, S.; Danesi, R.; De Braud, F.; De Pas, T.; Curigliano, G.; Giovannetti, E.; Del Tacca, M. Drug distribution and pharmacokinetic/pharmacodynamic relationship of paclitaxel and gemcitabine in patients with non-small-cell lung cancer. Ann. Oncol. 2001, 12, 1553-1559. [CrossRef]

27. Porter, J.B. Deferoxamine pharmacokinetics. Semin. Hematol. 2001, 38, 63-68. [CrossRef]

28. Mcdonnell, G.; Russell, A.D. Antiseptics and disinfectants: Activity, action, and resistance. Clin. Microbiol. Rev. 1999, 12, 147-179. [CrossRef]

29. Abbas, S.; Sastry, S. Chlorhexidine: Patient Bathing and Infection Prevention. Curr. Infect. Dis. Rep. 2016, 18, 25. [CrossRef]

30. Cassir, N.; Thomas, G.; Hraiech, S.; Brunet, J.; Fournier, P.E.; La Scola, B.; Papazian, L. Chlorhexidine daily bathing: Impact on health care-associated infections caused by gram-negative bacteria. Am. J. Infect. Control 2015, 43, 640-643. [CrossRef]

31. Shah, A.; Pasrija, C.; Boulos, F.; Pham, S.; Griffith, B.P.; Amoroso, A.; Sanchez, P.G.; Kon, Z.N. Decontamination and lung transplantation of a patient with cystic fibrosis with resistant infections. Ann. Thorac. Surg. 2019, 107, e239-e241. [CrossRef]

32. Reyes, K.; Bardossy, A.C.; Zervos, M. Vancomycin-Resistant Enterococci: Epidemiology, Infection Prevention, and Control. Infect. Dis. Clin. N. Am. 2016, 30, 953-965. [CrossRef] [PubMed]

33. Huang, S.S.; Singh, R.; McKinnell, J.A.; Park, S.; Gombosev, A.; Eells, S.J.; Gillen, D.L.; Kim, D.; Rashid, S.; Macias-Gil, R.; et al. Decolonization to reduce postdischarge infection risk among MRSA carriers. N. Engl. J. Med. 2019, 380, 638-650. [CrossRef]

34. Hayden, M.K.; Lin, M.Y.; Lolans, K.; Weiner, S.; Blom, D.; Moore, N.M.; Fogg, L.; Henry, D.; Lyles, R.; Thurlow, C.; et al. Prevention of colonization and infection by Klebsiella pneumoniae carbapenemase-producing enterobacteriaceae in long-term acute-care hospitals. Clin. Infect. Dis. 2015, 60, 1153-1161. [CrossRef] [PubMed]

35. Tacconelli, E.; Cataldo, M.A.; Dancer, S.J.; De Angelis, G.; Falcone, M.; Frank, U.; Kahlmeter, G.; Pan, A.; Petrosillo, N.; Rodríguez-Baño, J.; et al. ESCMID guidelines for the management of the infection control measures to reduce transmission of multidrug-resistant Gram-negative bacteria in hospitalized patients. Clin. Microbiol. Infect. 2014, 20, 1-55. [CrossRef] [PubMed]

36. Messika, J.; La Combe, B.; Ricard, J.-D. Oropharyngeal colonization: Epidemiology, treatment and ventilator-associated pneumonia prevention. Ann. Transl. Med. 2018, 6, 426. [CrossRef] [PubMed]

37. Ayerbe-Algaba, R.; Gil-Marqués, M.L.; Jiménez-Mejías, M.E.; Sánchez-Encinales, V.; Parra-Millán, R.; Pachón-Ibáñez, M.E.; Pachón, J.; Smani, Y. Synergistic Activity of Niclosamide in Combination with Colistin Against Colistin-Susceptible and Colistin-Resistant Acinetobacter baumannii and Klebsiella pneumoniae. Front. Cell. Infect. Microbiol. 2018, 8, 348. [CrossRef]

38. Domalaon, R.; Malaka De Silva, P.; Kumar, A.; Zhanel, G.G.; Schweizer, F. The anthelmintic drug niclosamide synergizes with colistin and reverses colistin resistance in Gram-negative bacilli. Antimicrob. Agents Chemother. 2019, 63, e02574-18. [CrossRef]

39. Mohammad, H.; AbdelKhalek, A.; Abutaleb, N.S.; Seleem, M.N. Repurposing niclosamide for intestinal decolonization of vancomycin-resistant enterococci. Int. J. Antimicrob. Agents 2018, 51, 897-904. [CrossRef]

40. Torres, N.S.; Abercrombie, J.J.; Srinivasan, A.; Lopez-Ribot, J.L.; Ramasubramanian, A.K.; Leung, K.P. Screening a commercial library of pharmacologically active small molecules against Staphylococcus aureus biofilms. Antimicrob. Agents Chemother. 2016, 60, 5663-5672. [CrossRef]

41. Montoya, M.C.; Krysan, D.J. Repurposing estrogen receptor antagonists for the treatment of infectious disease. MBio 2018, 9, e02272-18. [CrossRef] 
42. DeGraw, J.I.; Kisliuk, R.L.; Gaumont, Y.; Baugh, C.M. Antimicrobial Activity of 8-Deazafolic Acid. J. Med. Chem. 1974, 17, 470-471. [CrossRef] [PubMed]

43. Hamilton-Miller, J.M.T. Antimicrobial activity of 21 anti-neoplastic agents. Br. J. Cancer 1984, 49, 367-369. [CrossRef] [PubMed]

44. Elwell, L.P.; Ferone, R.; Freeman, G.A.; Fyfe, J.A.; Hill, J.A.; Ray, P.H.; Richards, C.A.; Singer, S.C.; Knick, V.B.; Rideout, J.L.; et al. Antibacterial activity and mechanism of action of $3^{\prime}$-azido-3'-deoxythymidine (BW A509U). Antimicrob. Agents Chemother. 1987, 31, 274-280. [CrossRef]

45. Serrano, L.; Lees, P. The applied pharmacology of azaperone in ponies. Res. Vet. Sci. 1976, 20, 316-323. [CrossRef]

46. Ren, Y.; Liu, T.; Song, G.; Hu, Y.; Liang, J. Determination of lomerizine in human plasma by liquid chromatography/tandem mass spectrometry and its application to a pharmacokinetic study. J. Chromatogr. B Anal. Technol. Biomed. Life Sci. 2014, 947-948, 96-102. [CrossRef] [PubMed]

47. Hu, Y.; Liu, L.; Zhang, X.; Feng, Y.; Zong, Z. In vitro activity of neomycin, streptomycin, paromomycin and apramycin against carbapenem-resistant Enterobacteriaceae clinical strains. Front. Microbiol. 2017, 8, 2275. [CrossRef]

48. Schneider, E.K.; Reyes-Ortega, F.; Velkov, T.; Li, J. Antibiotic-non-antibiotic combinations for combating extremely drug-resistant Gram-negative 'superbugs'. Essays Biochem. 2017, 61, 115-125. [CrossRef]

49. Raad, I.; Darouiche, R.; Hachem, R.; Mansouri, M.; Bodey, G.P. The Broad-Spectrum Activity and Efficacy of Catheters Coated With Minocycline and Rifampin. J. Infect. Dis. 1996, 173, 418-424. [CrossRef]

50. Isenberg, H.D.; Alperstein, P.; France, K. In vitro activity of ciprofloxacin, levofloxacin, and trovafloxacin, alone and in combination with $\beta$-lactams, against clinical isolates of Pseudomonas aeruginosa, Stenotrophomonas maltophilia, and Burkholderia cepacia. Diagn. Microbiol. Infect. Dis. 1999, 33, 81-86. [CrossRef]

51. AI-Hasan, M.N.; Wilson, J.W.; Lahr, B.D.; Thomsen, K.M.; Eckel-Passow, J.E.; Vetter, E.A.; Tleyjeh, I.M.; Baddour, L.M. Beta-lactam and fluoroquinolone combination antibiotic therapy for bacteremia caused by gram-negative bacilli. Antimicrob. Agents Chemother. 2009, 53, 1386-1394. [CrossRef]

52. Lee, H.J.; Bergen, P.J.; Bulitta, J.B.; Tsuji, B.; Forrest, A.; Nation, R.L.; Li, J. Synergistic activity of colistin and rifampin combination against multidrug-resistant Acinetobacter baumannii in an in vitro pharmacokinetic/ pharmacodynamic model. Antimicrob. Agents Chemother. 2013, 57, 3738-3745. [CrossRef]

53. Hu, Y.F.; Liu, C.P.; Wang, N.Y.; Shih, S.C. In vitro antibacterial activity of rifampicin in combination with imipenem, meropenem and doripenem against multidrug-resistant clinical isolates of Pseudomonas aeruginosa. BMC Infect. Dis. 2016, 16, 444. [CrossRef]

54. Bergen, P.J.; Forrest, A.; Bulitta, J.B.; Tsuji, B.T.; Sidjabat, H.E.; Paterson, D.L.; Li, J.; Nation, R.L. Clinically relevant plasma concentrations of colistin in combination with imipenem enhance pharmacodynamic activity against multidrug-resistant Pseudomonas aeruginosa at multiple inocula. Antimicrob. Agents Chemother. 2011, 55, 5134-5142. [CrossRef]

55. Torres, N.S.; Montelongo-Jauregui, D.; Abercrombie, J.J.; Srinivasan, A.; Lopez-Ribot, J.L.; Ramasubramanian, A.K.; Leung, K.P. Antimicrobial and antibiofilm activity of synergistic combinations of a commercially available small compound library with colistin against Pseudomonas aeruginosa. Front. Microbiol. 2018, 9, 2541. [CrossRef]

56. Sun, W.; Weingarten, R.A.; Xu, M.; Southall, N.; Dai, S.; Shinn, P.; Sanderson, P.E.; Williamson, P.R.; Frank, K.M.; Zheng, W. Rapid antimicrobial susceptibility test for identification of new therapeutics and drug combinations against multidrug-resistant bacteria. Emerg. Microbes Infect. 2016, 5, 1-11. [CrossRef] [PubMed]

57. Cleary, J.M.; Rosen, L.S.; Yoshida, K.; Rasco, D.; Shapiro, G.I.; Sun, W. A phase 1 study of the pharmacokinetics of nucleoside analog trifluridine and thymidine phosphorylase inhibitor tipiracil (components of TAS-102) vs trifluridine alone. Investig. New Drugs 2017, 35, 189-197. [CrossRef]

58. Huayhuaz, J.A.A.; Vitorino, H.A.; Campos, O.S.; Serrano, S.H.P.; Kaneko, T.M.; Espósito, B.P. Desferrioxamine and desferrioxamine-caffeine as carriers of aluminum and gallium to microbes via the Trojan Horse Effect. J. Trace Elem. Med. Biol. 2017, 41, 16-22. [CrossRef]

59. van Asbeck, B.S.; Marcelis, J.H.; Marx, J.J.M.; Struyvenberg, A.; van Kats, J.H.; Verhoef, J. Inhibition of bacterial multiplication by the iron chelator deferoxamine: Potentiating effect of ascorbic acid. Eur. J. Clin. Microbiol. 1983, 2, 426-431. [CrossRef] [PubMed]

60. Hartzen, S.H.; Frimodt-MØLler, N.; Thomsen, V.F. The antibacterial activity of a siderophore: The activity of deferoxamine in vitro and its influence on the effect of antibiotics against Escherichia coli, Proteus mirabilis and coagulase-negative staphylococci. APMIS 1994, 102, 219-226. [CrossRef] [PubMed]

61. Yssel, A.E.J.; Vanderleyden, J.; Steenackers, H.P. Repurposing of nucleoside-and nucleobase-derivative drugs as antibiotics and biofilm inhibitors. J. Antimicrob. Chemother. 2017, 72, 2156-2170. [CrossRef]

62. Hussein, M.H.; Schneider, E.K.; Elliott, A.G.; Han, M.; Reyes-Ortega, F.; Morris, F.; Blastovich, M.A.T.; Jasim, R.; Currie, B.; Mayo, M.; et al. From Breast Cancer to Antimicrobial: Combating Extremely Resistant Gram-Negative Superbugs Using Novel Combinations of Polymyxin B with Selective Estrogen Receptor Modulators. Microb. Drug Resist. 2017, 23, 640-650. [CrossRef] [PubMed]

63. Miró-Canturri, A.; Ayerbe-Algaba, R.; Smani, Y. Drug Repurposing for the Treatment of Bacterial and Fungal Infections. Front. Microbiol. 2019, 10, 41. [CrossRef] [PubMed]

64. Soo, V.; Kwan, B.; Quezada, H.; Castillo-Juárez, I.; Pérez-Eretza, B.; García-Contreras, S.; Martínez-Vázquez, M.; Wood, T.; García-Contreras, R. Repurposing of Anticancer Drugs for the Treatment of Bacterial Infections. Curr. Top. Med. Chem. 2017, 17, 1157-1176. [CrossRef] [PubMed] 
65. De Lastours, V.; Fantin, B. Résistance aux fluoroquinolones en 2013: Quel impact pour l'interniste? Rev. Med. Interne 2014, 35, 601-608. [CrossRef]

66. Karakonstantis, S.; Kritsotakis, E.I.; Gikas, A. Pandrug-resistant Gram-negative Bacteria: A Systematic Review of Current Epidemiology, Prognosis and Treatment Options. J. Antimicrob Chemother 2020, 75, 271-282. [CrossRef]

67. De Clercq, E. Antiviral drugs in current clinical use. J. Clin. Virol. 2004, 30, 115-133. [CrossRef]

68. Rhodes, K.A.; Schweizer, H.P. Antibiotic resistance in Burkholderia species. Drug Resist. Updat. 2016, 28, 82-90. [CrossRef]

69. Touret, F.; Gilles, M.; Barral, K.; Nougairède, A.; van Helden, J.; Decroly, E.; de Lamballerie, X.; Coutard, B. In vitro screening of a FDA approved chemical library reveals potential inhibitors of SARS-CoV-2 replication. Sci. Rep. 2020, 10, 13093. [CrossRef]

70. Patiño-Rodríguez, O.; Zapata-Morales, J.R.; Escobedo-Moratilla, A.; Díaz de León-Cabrero, M.; Torres-Roque, I.; Pérez-Urizar, J. Determination of Pinaverium Bromide in Human Plasma by a Sensitive and Robust UPLC-MS-MS Method and Application to a Pharmacokinetic Study in Mexican Subjects. J. Chromatogr. Sci. 2015, 53, 1373-1378. [CrossRef]

71. De Mattos, A.C.; Altmeyer, C.; Tominaga, T.T.; Khalil, N.M.; Mainardes, R.M. Polymeric nanoparticles for oral delivery of 5-fluorouracil: Formulation optimization, cytotoxicity assay and pre-clinical pharmacokinetics study. Eur. J. Pharm. Sci. 2016, 84, 83-91. [CrossRef]

72. Sawada, M.; Matsui, Y.; Okudaira, Y. Concentrations of a New Antitumor Agent, 1-hexylcarbamoyl-5-fluorouracil in Serum and Gynecologic Tumor Tissue. J. Jpn. Obstet. Gynecol. Soc. 1983, 35, 2421-2426.

73. Gaete, L.E.; Ortiz, M.; Soto, J.; Saavedra, I. Amiodarone absorption and elimination after oral and intravenous administration in healthy individuals. Rev. Med. Chil. 1995, 123, 713-719. [PubMed]

74. Ghobadi, C.; Mirhosseini, N.; Shiran, M.R.; Moghadamnia, A.; Lennard, M.S.; Ledger, W.L.; Rostami-Hodjegan, A. Single-dose pharmacokinetic study of clomiphene citrate isomers in anovular patients with polycystic ovary disease. J. Clin. Pharmacol. 2009, 49, 147-154. [CrossRef] [PubMed]

75. Binkhorst, L.; Kloth, J.S.L.; de Wit, A.S.; de Bruijn, P.; Lam, M.H.; Chaves, I.; Burger, H.; van Alphen, R.J.; Hamberg, P.; van Schaik, R.H.N.; et al. Circadian variation in tamoxifen pharmacokinetics in mice and breast cancer patients. Breast Cancer Res. Treat. 2015, 152, 119-128. [CrossRef]

76. Kavathiya, K.; Gurjar, M.; Patil, A.; Naik, M.; Noronha, V.; Joshi, A.; Gota, V.; Prabhash, K. A Comparative Pharmacokinetic Study of 2 Pemetrexed Formulations in Indian Adult Chemonaive Patients With Adenocarcinoma Stage III/IV Non-Small Cell Lung Cancer. Clin. Pharmacol. Drug Dev. 2017, 6, 234-239. [CrossRef]

77. Judson, I.; Maughan, T.; Beale, P.; Primrose, J.; Hoskin, P.; Hanwell, J.; Berry, C.; Walker, M.; Sutcliffe, F. Effects of impaired renal function on the pharmacokinetics of raltitrexed (Tomudex ZD1694). Br. J. Cancer 1998, 78, 1188-1193. [CrossRef]

78. Inoue, K.; Yuasa, H. Molecular basis for pharmacokinetics and pharmacodynamics of methotrexate in rheumatoid arthritis therapy. Drug Metab. Pharmacokinet. 2014, 29, 12-19. [CrossRef] 